\title{
Phagocytic Activity and Oxidative Burst of Granulocytes in Persons with Myeloperoxidase Deficiency ${ }^{1}$ )
}

\author{
Claudia E. Gerber, Selim Kuçi, Matthias Zipfel, Dietrich Niethammer and Gernot Bruchelt
}

Universitäts-Kinderklinik, Abt. Hämatologie und Onkologie, Eberhard-Karls-Universität Tübingen, Tübingen, Germany

Summary: In the present study, phagocytosis and the oxidative metabolism of neutrophil granulocytes from five clinically healthy persons with different degrees of myeloperoxidase deficiency were investigated and compared to those of normal persons. The identification of individuals with myeloperoxidase deficiency was performed with the Bayer/Technicon $\mathrm{H} 3$ blood cell counter, which differentiates the leukocytes by measuring the peroxidase activity. Neutrophils of three out of five investigated myeloperoxidase deficient persons showed extremly low peroxidase indices ( -53 and lower), but only the neutrophils of one person totally lacked myeloperoxidase. This was demonstrated by comparing myeloperoxidase mass concentration measured with an enzyme immunoassay, lack of $\mathrm{HOCl}$ production, and was further confirmed by measuring luminol- and lucigenin-enhanced chemiluminescence. Characteristically, myeloperoxidase deficient granulocytes showed a strikingly decreased luminol-enhanced chemiluminescence while the lucigenin-enhanced chemiluminescence was significantly increased compared to normal granulocytes. Although there is a DNA sequence homology of about $70 \%$, the activity of peroxidase in eosinophils was not affected in any myeloperoxidase deficient person investigated. Moreover, a person with a very rare defect of eosinophil peroxidase had completely normal myeloperoxidase activity. The lack of myeloperoxidase activity is compensated for by an increased phagocytic activity, an increased production of superoxide anion (lucigeninchemiluminescence) and probably by an alternative metabolism of $\mathrm{H}_{2} \mathrm{O}_{2}$; since persons lacking myeloperoxidase activity do not normally suffer from severe infections, $\mathrm{H}_{2} \mathrm{O}_{2}$ is obviously metabolized to other reactive oxygen substrates than $\mathrm{HOCl}$, e.g. to $\mathrm{OH}$-radicals.

\section{Introduction}

Neutrophil granulocytes are the first line of defence against invading microorganisms such as bacteria and fungi (1). Apart from other defence mechanisms, the generation of reactive oxygen compounds plays an important role in this process. After the activation of an NADPHoxidase $^{2}$ ) complex, superoxide anion is generated, which is disproportionated to oxygen and $\mathrm{H}_{2} \mathrm{O}_{2}$, from which the highly potent $\mathrm{HOCl}$ is generated in the myeloperoxidase reaction. Neutrophil granulocytes, and to a lesser degree monocytes, contain myeloperoxidase-rich azurophil granules. Eosinophil granulocytes contain another peroxidase, the eosinophil peroxidase, which shares about $70 \%$ DNA sequence homology with myeloperoxidase (2). The different pattern of peroxidase content in the white blood cell fraction is the basis for leukocyte differentiation by

\footnotetext{
1) This work was supported by a grant from the Fortüne-Programm of the University of Tübingen.

2) Enzymes:

Catalase, EC 1.11.1.6

Eosinophil peroxidase, EC 1.11.1.-

Myeloperoxidase, EC 1.11.1.7

NADPH-oxidase, EC 1.6.99.6

Superoxide dismutase, EC 1.15.1.1
}

an automatic blood cell counter, the Bayer/Technicon $\mathrm{H} 3$. The introduction of such systems in routine blood cell analysis contributed mainly to the detection of partial or complete myeloperoxidase deficiency, which is a rather frequent event (prevalence of $1: 2000-1: 4000$ ) (3). Considering the important role of $\mathrm{HOCl}$ for effective killing of microorganisms, it is surprising that most myeloperoxidase deficient persons do not suffer from life threatening infections more frequently than persons with normal myeloperoxidase activity. This fact stands in severe contrast to persons whose granulocytes are deficient in NADPH-oxidase (chronic granulomatous disease) and consequently do not produce any reactive oxygen compounds. Therefore, these cells are not able to kill pathogens that are catalase-positive and/or do not generate endogenous $\mathrm{H}_{2} \mathrm{O}_{2}$ (4). Thus, in myeloperoxidase deficient cells there is obviously an interplay of other mechanism, which compensate for the inability to generate $\mathrm{HOCl}$ from $\mathrm{H}_{2} \mathrm{O}_{2}$.

In the present study, we characterize the phagocytic activity and the oxygen metabolism of granulocytes in 5 clinically healthy persons with different degrees of myeloperoxidase deficiency compared to persons with normal myeloperoxidase content. 


\section{Mlaterials and Methods}

Probands

Five clinically healthy myeloperoxidase deficient blood donors ( 4 females, I male) (mean peroxidase index ranged between -30 and -58 ) werc found by routine analysis on the Bayer/Technicon $\mathrm{H} 3$. They are unrelated probands and their age ranged from 25-40 years. Proband 6 (a six year old girl. suffering from dystrophia of unclear origin) with a rare eosinophil peroxidase deficiency was found by routine blood measurement on the H3. Normal blood controls of 5 healthy persons, aged between $25-45$ years, were sclected. based on their myeloperoxidase activity. Founded on measurements of several thousand healthy donors, the mean peroxidase index was arbitrarily set as "zero" by the manufacturer $(5,6)$ and the values of the mean peroxidase index between +10 and -10 were considered as 'normal'. The mean peroxidase index of an individual sample was calculated by the $\mathrm{H} 3$ according to the equation:

$$
\frac{(\mathrm{MPX}) \mathrm{a}-(\mathrm{MPX}) \mathrm{n}}{(\mathrm{MPX}) \mathrm{n}} \times 100=\text { mean peroxidase index }
$$

(MPX)a: mean peroxidase activity of the current sample (MPX)n: mean peroxidase activity of a collection of normal donors.

\section{Cell counting and measurement of myeloperoxidase activity}

Blood cell analysis was carried out by flow cytometry using the Bayer/Technicon H3. Differentiation of leukocytes was performed by peroxidase staining and by simultaneous measurement of lightscattering ("perox-chanel"). For peroxidase staining, red cells were lysed in the H3-integrated "perox-chamber", and leukocytes were fixed with formalin and stained for peroxidase using $\mathrm{H}_{2} \mathrm{O}_{2}$ and 4chloro-1-naphthol as chromogen $(7,8)$. The cell distribution pattern was plotted by a socalled leukogram with peroxidase activity on the $x$-axis and light-scattering on the $y$-axis (see fig. 1). In parallel, low and wide angle scattering of cell nuclei is also registrated ("basophilic chanel", not shown in fig. 1).

\section{Chemicals and media}

Histopaque $^{\circledR} 1119$ and 1077; phorbol 12-myristate 13-acetate; catalase (40 000-60000 U/mg); superoxide dismutase (30000 U/mg); bovine serum albumin; ferricytochrome c; 5,5'-dithio-bis(2-nitrobenzoic acid); Na-dithionite; 5-amino-2,3-dihydro-1.4-phthalazinedione (luminol) and bis- $\mathrm{N}$-methylacridinium nitrate (lucigenin) were purchased from Sigma (München, Germany). Hanks' balanced salt solution (with $\mathrm{Ca}^{2+} / \mathrm{Mg}^{2+}$, but without phenol red) and phosphate buffered saline were purchased from Biochrom (Berlin, Germany); Zymosan: from ICN (Eschwege, Germany) and $\mathrm{H}_{2} \mathrm{O}_{2}$ $(300 \mathrm{~g} / \mathrm{kg}$ ) from Merck (Darmstadt, Germany).

Opsonized zymosan was prepared by incubation of $250 \mathrm{mg}$ zymosan with $25 \mathrm{ml}$ of human pool serum for 30 minutes at $37^{\circ} \mathrm{C}$. After washing, opsonized zymosan was suspended in $3.5 \mathrm{ml}$ phosphate buffered saline and frozen until use (9).

\section{Isolation of polymorphonuclear leukocytes}

Polymorphonuclear leukocytes were isolated from heparinized whole blood loaded on a two step density gradient with Histopaque ${ }^{\circledR} 1119$ and 1077 by centrifugation at $500 \mathrm{~g}$, at $21^{\circ} \mathrm{C}$ for 25 minutes. Polymorphonuclear leukocytes were collected, washed twice in Hanks' balanced salt solution with $\mathrm{Ca}^{2+} / \mathrm{Mg}^{2+}$ and contaminating erythrocytes were lysed using an ice-cold ammonium chloride buffer $(8.29 \mathrm{~g} / \mathrm{l})$ for 15 minutes. The resulting polymorphonuclear leukocytes were counted and adjusted to the desired concentration by adding Hanks' balanced salt solution with $\mathrm{Ca}^{2+}$ $\mathrm{Mg}^{2+}$.

For separating the eosinophil granulocytes from neutrophils, the magnetic cell sorter technique (Miltenyi Biotec, Bergisch Gladbach, Germany) was used (10). Cells were incubated with an antiCD16-antibody conjugated with superparamagnetic microbeads
(Miltenyi Biotec, Bergisch Gladbach, Germany). Incubating the granulocytes with this antibody leads to a binding of marked neutrophils by passing the ccll-suspension through a magnetic column. The unmarked eosinophils are found in the eluate (purity $82 \%$ ), the neutrophils are retained and washed out with phosphate buffered saline after separating the column from the magnetic field (purity 98\%). The resulting cells were used for determination of cross-reactivity of myeloperoxidase and cosinophil peroxidase with the enzyme immunoassay (see below).

\section{Phagocytosis assay}

A commercially available test kit from Orpegen (Heidelberg, Germany) was used according to the manufacturer's instructions. The test was intended to investigate the phagocytic activity of polymorphonuclear leukocytes and macrophages by flow cytometry adding fluorescein isothiocyanate-loaded $E$. coli. Fluorescence activated cell scan analysis permits the determination of the percentage of granulocytes which can phagocytose fluorescein isothiocyanate-labeled $E$. coli as well as phagocytic activity of every individual cell. Flow cytometry was carried out on a fluorescence activated cell scan from Becton-Dickinson (Heidelberg, Germany). The data were analyzed using the Lysis II program from Becton-Dickinson.

\section{Myeloperoxidase enzyme immunoassay}

The myeloperoxidase enzyme immunoassay kit (Biermann, Bad Nauheim, Germany) is an enzyme linked immunosorbent assay for measuring myeloperoxidase mass concentrations in several biological samples. Isolated granulocytes $\left(2 \times 10^{6}\right.$ cells, or in some experiments, neutrophils and eosinophils, previously separated by magnetic cell sorting) were homogenized in $1 \mathrm{ml}$ Tween 80/phosphate buffered saline $(1 \mathrm{ml} / \mathrm{l})$ by 3 cycles of freezing $\left(-70^{\circ} \mathrm{C}\right)$ and thawing $\left(37^{\circ} \mathrm{C}\right)$ and sonicated for 30 seconds. The final suspension was centrifuged at $12000 \mathrm{~g}$ for 15 minutes and the supernatant was collected and analyzed. The immunological cross-reactivity toward the eosinophil peroxidase has been evaluated as lower than $2 \%$ (product information of Biermann, Bad Nauheim).

\section{$\mathrm{O}_{2}$ consumption and $\mathrm{H}_{2} \mathrm{O}_{2}$ measurement}

The initial rate of oxygen consumption of polymorphonuclear leukocytes $\left(3.75 \times 10^{6} / 1 \mathrm{ml}\right.$ Hanks' balanced salt solution) was measured under basal and stimulated conditions (addition of $100 \mu \mathrm{l}$ opsonized zymosan (10:1 diluted)) using a Clark electrode (Bachofer, Reutlingen, Germany) at $37^{\circ} \mathrm{C}$ for $5-10$ minutes (9). The steadystate concentration of $\mathrm{H}_{2} \mathrm{O}_{2}$ was measured 5 minutes after the addition of opsonized zymosan to the cell suspension. For this purpose, $10 \mu \mathrm{l}$ of catalase solution [60 units] were added to the incubation chamber and the increase in oxygen was monitored according to the equation

$$
\mathrm{H}_{2} \mathrm{O}_{2} \rightarrow \mathrm{H}_{2} \mathrm{O}+1 / 2 \mathrm{O}_{2}
$$

An $\mathrm{H}_{2} \mathrm{O}_{2}$ calibration curve was established by adding increasing amounts of $\mathrm{H}_{2} \mathrm{O}_{2}$ to $1 \mathrm{ml}$ incubation buffer [containing 60 units catalase] which was previously partially deoxygenated by a stepwise addition of small amounts of sodium dithionite.

\section{Superoxide anion assay}

Superoxide anion production was determined as superoxide dismutase-inhibitable reduction of ferricytochrome $\mathrm{c}$ by a microassay according to Mayo \& Curnutte (11). Into each well of a 96-well plate $50 \mu \mathrm{l}$ of the polymorphonuclear leukocyte suspension $(7.5$ $\left.\times 10^{9} / \mathrm{l}\right), 50 \mu \mathrm{l}$ ferricytochrome $\mathrm{c}(2.7 \mathrm{~g} / \mathrm{l})$ and bovine serum albu$\mathrm{min} /$ Hanks' balanced salt solution $(80 \mathrm{~g} / \mathrm{l})$ were placed. Into reference wells $50 \mu \mathrm{l}$ of superoxide dismutase $(1.25 \mathrm{~g} / \mathrm{l})$ were added. Granulocytes were stimulated with phorbol myristate acetate $(20$ $\mu \mathrm{g} / \mathrm{l}$ ) and incubated at $37^{\circ} \mathrm{C}$ for 30 minutes. Thereafter, wells were measured at $550 \mathrm{~nm}$ with a microplate reader (Dynatech, Denkendorf, Germany). After complete reduction of ferricytochrome $\mathrm{c}$ by addition of $10 \mu \mathrm{l} \mathrm{Na}$-dithionite (half-saturated solution), the whole amount of reduced ferricytochrome $\mathrm{c}$ was measured again at 550 $\mathrm{nm}$ to obtain the relation of the ferricytochrome reduced by $\mathrm{O}_{2}^{-}$ 
and the total amount of ferricytochrome. $\mathrm{O} \dot{\overline{2}}$ produced by polymorphonuclear leukocytes was calculated as the difference between superoxide dismutase-containing samples and samples without superoxide dismutase (relation of reduced to total reduced ferricytochrome c).

\section{HOCl assay}

The $\mathrm{HOCl}$ production of polymorphonuclear leukocytes $(3.75$ $\left.\times 10^{9} / 1\right)$ was measured by the chlorination of taurine followed by the oxidation of 5-thio-2-nitrobenzoic acid to 5,5'-dithio-bis(2nitrobenzoic acid) (12). Polymorphonuclear leukocytes $(1 \mathrm{ml})$ were incubated in Hanks' balanced salt solution/taurine $(15 \mathrm{mmol} / \mathrm{l})$ and stimulated with $100 \mu \mathrm{l}$ opsonized zymosan (stock suspension $1: 10$ diluted) at $37^{\circ} \mathrm{C}$ for 30 minutes. After stopping the reaction by adding catalase (290 units), samples were centrifuged at $12000 \mathrm{~g}$ for 10 minutes. The supernatant was mixed with freshly prepared and diluted 5-thio-2-nitrobenzoic acid solution $(\sim 2 \mathrm{mmol} / \mathrm{l})$ and immediately measured at $412 \mathrm{~nm}$ in a UV-spectrometer (LKB Ultrospec Plus; Pharmacia, Freiburg. Germany). The amount of $\mathrm{HOCl}$ produced was calculated using the molar linear absorption coefficient $\varepsilon=1410 \mathrm{~m}^{2} / \mathrm{mol}$ in consideration of the dilution factor (13). Negative controls were prepared by adding Na-azide (100 $\mu \mathrm{mol} / \mathrm{l}), L$-methionine $(1 \mathrm{mmol} / \mathrm{l})$ and catalase (290 units) to the same cell concentration and opsonized zymosan as stimulator.

\section{Chemiluminescence test conditions}

Chemiluminescence assays were performed on a Biolumat (LB 9505; Berthold, Wildbad, Germany). The results were evaluated with an Apple II using the 'BIO' program. Samples of whole heparinized blood were first diluted 1:100 with phosphate buffered saline. Diluted blood $(200 \mu \mathrm{l})$ samples plus $680 \mu \mathrm{l}$ phosphatc buf- fered saline with $\mathrm{Ca}^{2+} / \mathrm{Mg}^{2+}$ plus $100 \mu \mathrm{l}$ luminol $(200 \mu \mathrm{mol} / \mathrm{l})$ or lucigenin $(1 \mathrm{mmol} / \mathrm{l})$ were preincubated at $37^{\circ} \mathrm{C}$ for 10 minutes. The stimulation was started by adding $20 \mu \mathrm{l}$ of opsonized zymosan ( $1: 10$ diluted). The reaction was monitored at $37^{\circ} \mathrm{C}$ for $50 \mathrm{~min}$ utes.

\section{Stalistics}

The data are expressed as mean ( \pm SD if $n \geq 3$ ). Statistical comparisons were performed with Mann-Whitney U-test ( $\alpha: 0.05)$ and using lincar regression.

\section{Results}

\section{Identification of myeloperoxidase deficient individuals using the $\mathrm{H} 3$}

Figure 1 shows the leukograms (peroxidase activity) of five probands (proband 1-5) with different myeloperoxidase deficiencies compared to those of a normal person (control) and a proband (proband 6) with eosinophil pcroxidase deficiency. Three of the five myeloperoxidase deficient probands showed extremely low mean peroxidase indices ( -53 or less). Therefore, their neutrophil clusters were clearly shifted to the left. However, in only one out of these three persons $1-3$ were the neutrophils and monocytes completely located in the large unstained cell area (fig. 1, proband 1), suggesting
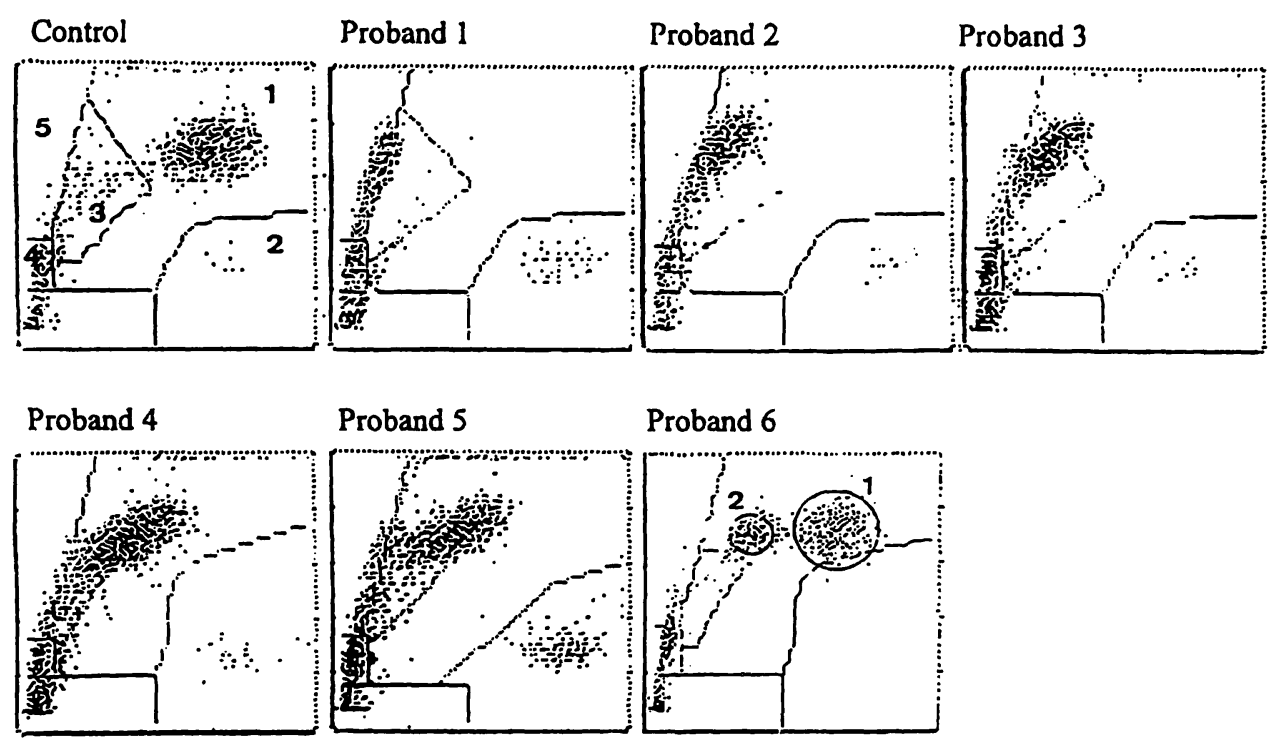

Fig. 1 Leukograms of the Bayer/Technicon $\mathrm{H} 3$ of a normal donor (control), five myeloperoxidase deficient donors of different degrees (proband 1-5) and one blood count presenting the rare deficiency of eosinophil peroxidase (proband 6). Light-scattering is plotted on the $y$-axis, the myeloperoxidase activity is plotted on

Proband 6

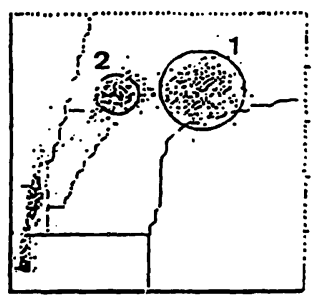

the $x$-axis. The numbers indicate the following cells: 1 neutrophils, 2 eosinophils, 3 monocytes. 4 lymphocytes, 5 large unstained cells. Corresponding microscopic analyses of the blood cells are as follows: Corresponding microscopic analyses

\begin{tabular}{|c|c|c|c|c|c|}
\hline & $\begin{array}{l}\text { Mean peroxidase } \\
\text { index }\end{array}$ & $\begin{array}{l}\text { Neutrophils } \\
(\%)\end{array}$ & $\begin{array}{l}\text { Eosinophils } \\
(\%)\end{array}$ & $\begin{array}{l}\text { Monocytes } \\
(\%)\end{array}$ & $\begin{array}{l}\text { Lymphocytes } \\
(\%)\end{array}$ \\
\hline Control & +3.2 & 55 & 3 & 5 & 37 \\
\hline Proband 1 & -59.1 & 66 & 4 & 5 & 25 \\
\hline Proband 2 & -59.3 & 54 & 0 & 8 & 38 \\
\hline Proband 3 & -53.3 & 67 & 1 & 5 & 27 \\
\hline Proband 4 & -42.8 & 68 & 1 & 6 & 25 \\
\hline Proband 5 & -32.6 & 63 & 2 & 2 & 33 \\
\hline Proband 6 & -22.5 & 31 & 18 & 7 & 44 \\
\hline
\end{tabular}


Tab. 1 Mean peroxidase index, myeloperoxidase mass [ng/106 granulocytes], $\mathrm{HOCl}$ production [ $\mathrm{nmol} \mathrm{HOCl} / 30 \mathrm{~min}$ ] and phagocytic activity [\%] of normal (control, was set as 100\%) and mycloperoxidase deficient cells [proband $1-5$ ]. The $\mathrm{HOCl}$ production was measured using $1 \mathrm{ml}$ isolated granulocytes (3.75 $\left.\times 10^{9} / 1\right)$ and opsonized zymosan as a stimulus. Phagocytosis was measured in whole blood after incubation with fluoresccin isothiocyanate-labeled $E$. coli.

\begin{tabular}{|c|c|c|c|c|c|c|}
\hline & \multirow{2}{*}{ Control } & \multicolumn{5}{|l|}{ Proband no. } \\
\hline & & 1 & 2 & 3 & 4 & 5 \\
\hline Mean peroxidase index & $-4.6 \pm 3.3$ & $-54 \pm 4.8$ & $-57 \pm 3.1$ & $-53 \pm 3.0$ & $-39 \pm 3.0$ & $-33 \pm 2.8$ \\
\hline $\begin{array}{l}\text { Myeloperoxidase mass } \\
\text { (ng/106 granulocytes) }\end{array}$ & 1053 & 0 & 99 & 156 & 314 & 589 \\
\hline $\begin{array}{l}\mathrm{HOCl} \text { production } \\
(\mathrm{nmol} / 30 \mathrm{~min})\end{array}$ & $446 \pm 52$ & 0 & $81 \pm 42$ & $134 \pm 31$ & $138 ; \neq 27$ & $158 \pm 34$ \\
\hline $\begin{array}{l}\text { Phagocytic activity/ } \\
\text { granulocyte population } \\
\text { (\% of normal) }\end{array}$ & $98.2 \pm 0.8$ & $99.1 \pm 0.3$ & $98.7 \pm 0.9$ & $99.6 \pm 0.2$ & $97.9 \pm 1.1$ & $98 \pm 1$ \\
\hline $\begin{array}{l}\text { Phagocytic activity/ } \\
\text { single granulocyte } \\
\text { (\% of normal) }\end{array}$ & 100 & $141 \pm 17$ & $155 \pm 7$ & $146 \pm 15$ & $122 \pm 20$ & $154 \pm 19$ \\
\hline
\end{tabular}

Mean \pm SD; PI-P5: $n=3$; control: $n=6$

that only the cells of this person could be totally myeloperoxidase deficient. As will be shown, this could also be confirmed by other tests. The clusters of eosinophil granulocytes of persons with myeloperoxidase deficiency did not differ from controls. For comparison, the leukogram of proband 6 with a very rare form of eosinophil peroxidase deficiency is shown in figure 1. Due to lacking stained vesicles, the light-scattering is changed characteristically, leading to a cluster location upwards on the $y$-axis, and a shift to the left on the $x$-axis. The myeloperoxidase activity was normal (as shown by the location of the neutrophils in the leukogram). However, because of the unusual plotting of the eosinophil granulocytes, the calculation of the mean peroxidase index -22.5 ) is wrong.

\section{Phagocytic behaviour of myeloperoxidase deficient granulocytes}

Ninety-seven to $98 \%$ of cells of the whole myeloperoxidase deficient neutrophil population were able to phagocytose fluorescein isothiocyanate-labelled $E$. coli, which was not different from neutrophils with normal myeloperoxidase activity. In contrast, the phagocytic activity of every single cell in the population was remarkably higher than in normal controls (tab. 1).

\section{Correlation between myeloperoxidase activity, myeloperoxidase content and $\mathrm{HOCl}$ production}

In order to explore in further detail whether the $\mathrm{H} 3$ measurements of myeloperoxidase activity correlated to the amount of myeloperoxidase in the neutrophils, granulocytes were isolated and myeloperoxidase concentration was assayed using a myeloperoxidase enzyme immunoassay. Figure 2 shows a good linear correlation between these two quantities $(r=0.97)$. However, among the
Measurements were carried out during a time period of 9 months.

three probands with a very low mean peroxidase index (below -53), myeloperoxidase was completely absent only in one person (proband 1). In accordance with this finding, only the neutrophils of this person were unable to produce $\mathrm{HOCl}$ (tab. 1). Although the mean peroxidase index indicated for proband 2 was comparably low, detectable amounts of myeloperoxidase (enzyme immunoassay) and low $\mathrm{HOCl}$ production were found in her neutrophils (tab. 1). Obviously, the mean peroxidase index cannot be calculated with exactness in this very low range. A more successful way of identifying persons with complete myeloperoxidase deficiency is the evaluation of the graphic presentation (fig. 1), which clearly shows that only the neutrophils of proband 1 are located completely in the large unstained cell area.

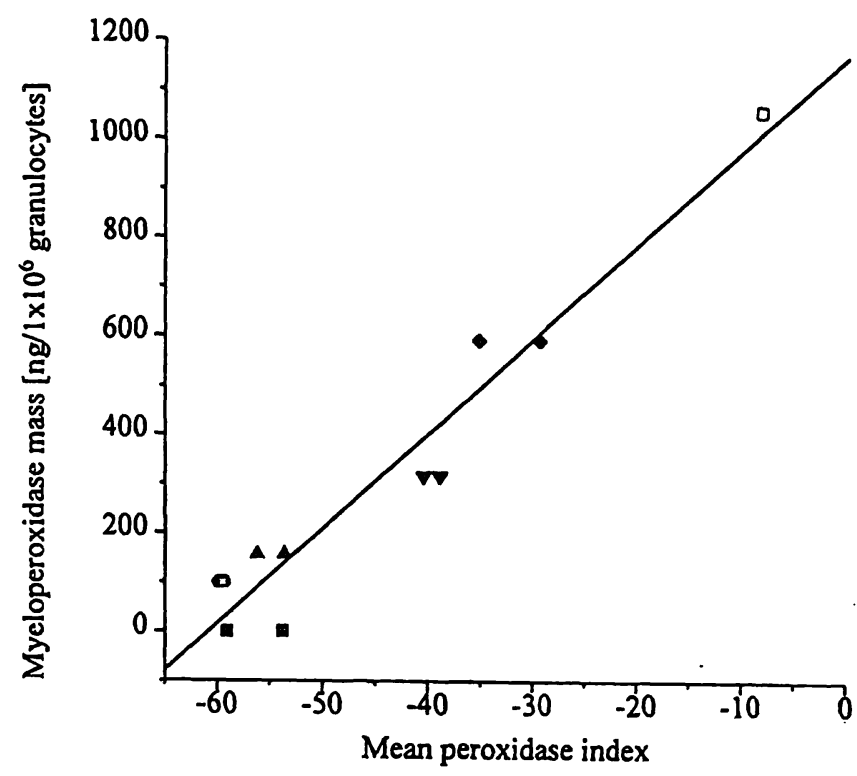

Fig. 2 Comparison between the mean peroxidase index (myeloperoxidase activity) measured on the Bayer/Technicon $\mathrm{H} 3$ and the myeloperoxidase mass $\left[\mathrm{ng} / 1 \times 10^{6}\right.$ granulocytes] analyzed using an enzyme immunoassay. $r=0.97, y=19 x+1165$.

- Proband 1

- Proband 2
Proband 5

a Control. 
Tab. 2 Luminol- and lucigenin-enhanced chemiluminescence of normal and myeloperoxidase deficient cells during stimulation of opsonized zymosan.
Data are presented as integral counts $(0-60$ minutes), peak and

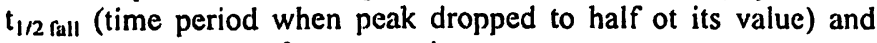
expressed as mean of two experiments.

\begin{tabular}{|c|c|c|c|c|c|c|}
\hline \multirow[t]{2}{*}{ Chemiluminescence } & \multirow[t]{2}{*}{ Control } & \multicolumn{5}{|c|}{ Proband no. } \\
\hline & & 1 & 2 & 3 & 4 & 5 \\
\hline \multicolumn{7}{|l|}{ Luminol } \\
\hline $\begin{array}{l}\text { Integral }\left[10^{3} \text { counts } / \mathrm{min}\right] \\
\text { Peak }\left[10^{3} \text { counts } / \mathrm{min}\right] \\
t_{1 / 2}[\mathrm{~min}]\end{array}$ & $\begin{array}{r}47294 \\
1586 \\
42\end{array}$ & $\begin{array}{r}5716 \\
126 \\
>60\end{array}$ & $\begin{array}{r}29721 \\
834 \\
53\end{array}$ & $\begin{array}{r}49037 \\
1574 \\
41\end{array}$ & $\begin{array}{r}51976 \\
1666 \\
49\end{array}$ & $\begin{array}{r}32706 \\
1039 \\
48\end{array}$ \\
\hline \multicolumn{7}{|l|}{ Lucigenin } \\
\hline $\begin{array}{l}\text { Integral }\left[10^{3} \text { counts } / \mathrm{min}\right] \\
\text { Peak }\left[10^{3} \text { counts } / \mathrm{min}\right] \\
t_{1 / 2}[\mathrm{~min}]\end{array}$ & $\begin{array}{r}31668 \\
888 \\
50\end{array}$ & $\begin{array}{r}93542 \\
2390 \\
59\end{array}$ & $\begin{array}{r}85624 \\
2143 \\
>60\end{array}$ & $\begin{array}{r}97948 \\
2420 \\
60\end{array}$ & $\begin{array}{r}47563 \\
1106 \\
>60\end{array}$ & $\begin{array}{r}44356 \\
1121 \\
>60\end{array}$ \\
\hline
\end{tabular}

Chemiluminescence assay with normal and myeloperoxidase negative granulocytes

Chemiluminescence tests with luminol and lucigenin showed characteristic differences between myeloperoxidase negative and myeloperoxidase positive cells. The cells of proband 1 which were unable to produce $\mathrm{HOCl}$ (see tabs. 1 and 2) showed a drastic decrease of luminol dependent chemiluminescence compared to controls (fig. 3a). In contrast, the lucigenin dependent chemiluminescence was remarkably enhanced compared to the control. The higher signals of lucigenin mediated chemiluminescence correspond with the higher superoxide anion production measured by the ferricytochrome $\mathrm{c}$ method after stimulation with phorbol myristate acetate [20 $\mu \mathrm{g} / \mathrm{l}]$. Proband 1 produced $119 \mathrm{nmol} / 3.75 \times 10^{5}$ cells per $30 \mathrm{~min}$ compared to the $88 \mathrm{nmol} / 3.75 \times 10^{5}$ cells per $30 \mathrm{~min}$ of the control. Furthermore, the duration of photon emission lasted longer than in normal controls (indicated as $t_{1 / 2 \text { fall }}$ : the time period when the chemiluminescence peak maximum dropped to half of its value; fig. 3) (tab. 2). A similar pattern in lucigenin chemilumi- nescence was also detected in partially myeloperoxidase deficient granulocytes compared with controls.

$\mathrm{O}_{2}$ consumption and $\mathrm{H}_{2} \mathrm{O}_{2}$ steadystate concentration of normal and myeloperoxidase deficient granulocytes

Oxygen consumption and $\mathrm{H}_{2} \mathrm{O}_{2}$ steadystate concentration were determined after the activation of isolated granulocytes with opsonized zymosan in a Clark electrode $\left(3.75 \times 10^{6}\right.$ cells $/ 1 \mathrm{ml}$ incubation buffer) (fig. 4). Within the first 5 minutes there was no great difference of net oxygen consumption between normal and myeloperoxidase deficient granulocytes $\left[\begin{array}{ll}169 & \pm 20\end{array}\right.$ $\mathrm{nmol} / 3.75 \times 10^{6}$ cells per $5 \mathrm{~min}$ (control) vs. $153 \pm 10$ nmol/3.75 $\times 10^{6}$ cells per 5 min (proband 1 ), mean of 3 independent experiments, $\pm \mathrm{SD}$ ]. It was expected that the $\mathrm{H}_{2} \mathrm{O}_{2}$ concentration of myeloperoxidase deficient granulocytes (proband 1) would be higher due to their inability to convert it to $\mathrm{HOCl}$. Indeed, there was a slightly higher $\mathrm{H}_{2} \mathrm{O}_{2}$ concentration in myeloperoxidase negative cells: $6.21 \pm 4.4 \mathrm{nmol} / 3.75 \times 10^{6}$ cells per

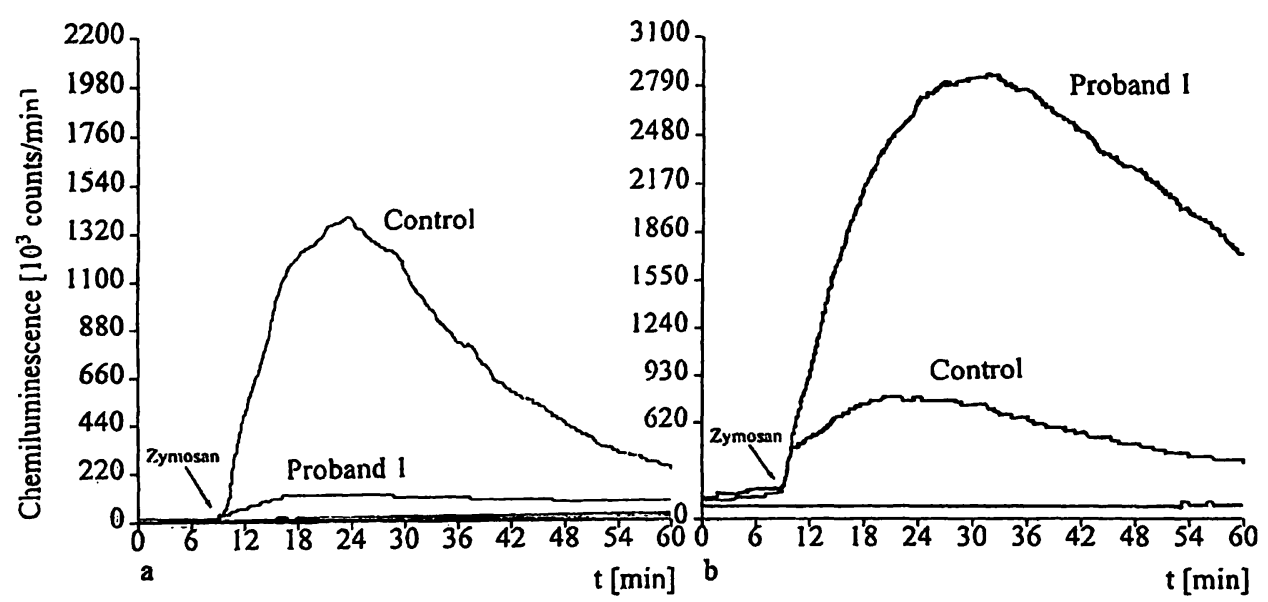

Fig. 3 Chemiluminescence measurement of the cells (whole blood diluted $1: 100$ with phosphate buffered saline) from proband 1 with total myeloperoxidase deficiency compared to a control. a: Luminol-enhanced chemiluminescence after stimulation with opsonized zymosan.

b: Lucigenin-enhanced chemiluminescence after stimulation with opsonized zymosan. 

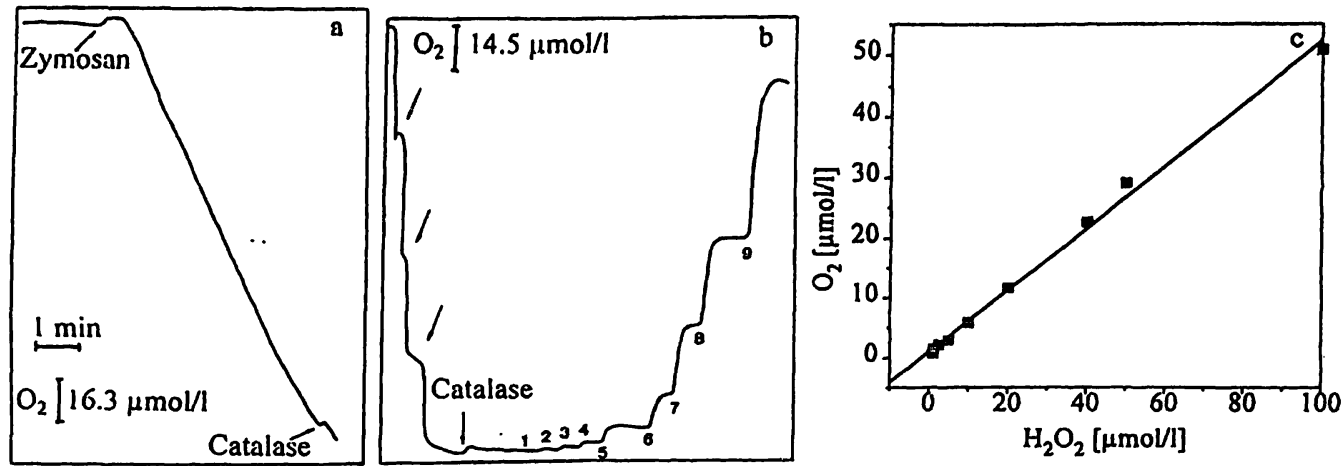

Fig. 4 a Oxygen consumption and concentration of $\mathrm{H}_{2} \mathrm{O}_{2}$ measured with the Clark electrode. Granulocytes, $1 \mathrm{ml}\left(3.75 \times 10^{9} / 1\right)$ were incubated in the reaction chamber and stimulated with opsonized zymosan. After an incubation period of about 5 minutes the steady'state concentration of $\mathrm{H}_{2} \mathrm{O}_{2}$ was determined by adding catalase $(60 \mathrm{kU} / \mathrm{l})$.

Fig. 4 b $\mathrm{H}_{2} \mathrm{O}_{2}$ calibration curve ivas established by addition of different amounts of $\mathrm{H}_{2} \mathrm{O}_{2}$ to the incubation buffer containing catalase according to the equation:

$$
\mathrm{H}_{2} \mathrm{O}_{2} \stackrel{\text { Catalase }}{\longrightarrow} \mathrm{H}_{2} \mathrm{O}+1 / 2 \mathrm{O}_{2}
$$

$5 \mathrm{~min}$ (proband 1 ) vs. $4.83 \pm 5.0 \mathrm{nmol} / 3.75 \times 10^{6}$ cells per $5 \min (n=3)$. However, the steadystate concentration of $\mathrm{H}_{2} \mathrm{O}_{2}$ was rather low, not only in normal granulocytes as expected, but also in myeloperoxidase deficient granulocytes. $\mathrm{H}_{2} \mathrm{O}_{2}$ was determined 5 minutes after addition of the stimulus zymosan by adding catalase, considering the fact that $\mathrm{H}_{2} \mathrm{O}_{2}$ can easily penetrate cell membranes and exit the cells (14). As can be arbitrarily calculated from one experiment shown in figure 4 and from equation (1), $161+80.5=241.5 \mathrm{nmol}$ oxygen were consumed by normal granulocytes during the first 5 minutes, which could, theoretically, allow a maximal production of $80.5 \mathrm{nmol} \mathrm{H}_{2} \mathrm{O}_{2}$.

$$
\begin{aligned}
& {\left[2 \mathrm{O}_{2}+2 \mathrm{NADPH} \rightarrow 2 \mathrm{HO}_{2} \leftrightarrow 2 \mathrm{H}^{+}\right.} \\
& \left.\quad+2 \mathrm{O}_{2}^{-} \rightarrow \mathrm{H}_{2} \mathrm{O}_{2}+\mathrm{O}_{2}\right]
\end{aligned}
$$

However, only $3.02 \mathrm{nmol} / 3.75 \times 10^{6}$ cells per $5 \mathrm{~min}$ $\mathrm{H}_{2} \mathrm{O}_{2}$ were detected in normal granulocytes and 5.44 $\mathrm{nmol} / 3.75 \times 10^{6}$ cells per $5 \mathrm{~min}$ in myeloperoxidase deficient granulocytes. Since myeloperoxidase positive and negative granulocytes probably do not differ in their catalase and glutathione-peroxidase activities $(15,16)$, it is obvious that myeloperoxidase deficient granulocytes use other compensatory $\mathrm{H}_{2} \mathrm{O}_{2}$ consuming pathways for generating antimicrobial oxygen species (e.g. OH-radicals), instead of generating $\mathrm{HOCl}$.

\section{Discussion}

Correlation between myeloperoxidase activity, myeloperoxidase content and $\mathrm{HOCl}$ production

Mean peroxidase indices below -55 are generally thought to reflect a total myeloperoxidase deficiency (17). However, in granulocytes with very low myeloper-
Arrows: Stepwise addition of Na-dithionite $(10 \mu l$ of a half-saturated solution) to reduce the oxygen content in the reaction chamber before starting the reaction.

Numbers: addition of $\mathrm{H}_{2} \mathrm{O}_{2}$ standards [ $\left.\mu \mathrm{mol} / 1\right] 1: 1.0 ; 2: 1.25 ; 3$ : 2.5; 4: 5.0; 5: 10.0; 6: 20,0; 7: 40.0; 8: 50.0; 9: 100.0 .

Fig. $4 \mathrm{c} \mathrm{H}_{2} \mathrm{O}_{2}$ calibration curve according to the data of fig. $4 \mathrm{~b}$ $(r=0.988, y=0.51 x+1.0)$.

oxidase activity, these values may not be estimated with exactness. In our opinion, much better results are achieved by considering the graphical presentation, i.e. whether the neutrophils (and monocytes) are completely in the large unstained cell area or slightly shifted to the right (fig. 1). Neutrophils/monocytes of proband 1, which were clearly located in the large unstained cell region, did not give a signal in the myeloperoxidase enzyme immunoassay. Generally, there was a good correlation between myeloperoxidase activity (Bayer/ Technicon H3) and the amount of myeloperoxidase in cell extracts measured by the enzyme immunoassay (fig. 2).

However, it should be noted that even in the complete absence of myeloperoxidase activity, enzyme immunoassay signals could be positive since there is a crossreactivity between eosinophil peroxidase and myeloperoxidase (18). In experiments using cell extracts of neutrophils and eosinophils previously separated by the magnetic activated cell sorter technique, using antiCD16 antibodies, we observed this cross-reactivity: In extracts of $10^{6}$ neutrophils (purity: 98\%), $370 \mathrm{ng}$ myeloperoxidase could be detected, in $10^{6}$ eosinophils (purity: $82 \%, 18 \%$ neutrophils and monocytes) an amount of eosinophil peroxidase, which corresponded to $115 \mathrm{ng}$ of myeloperoxidase. Comparing $10^{6}$ neutrophils with $10^{6}$ eosinophils (the real amount of eosinophil peroxidase was not known), the net eosinophil peroxidase/myeloperoxidase cross-reactivity (subtraction of the $18 \%$ ) would be about $10 \%$ and can therefore be neglected under normal conditions (whole blood), where the amount of neutrophils is significantly higher than the amount of eosinophils. According to the manufacturer (Biermann, Bad Nauheim, Germany), the cross-reactivity of eonsinophil peroxidase with myeloperoxidase is lower than 
$2 \%$. In extracts of granulocytes of proband 1 we could not find any peroxidase using the enzyme immunoassay. Obviously, the amount of eosinophils was too small to detect any eosinophil peroxidase crossreactivity. Since $\mathrm{HOCl}$ production was also lacking, proband 1 could definitively be regarded as completely myeloperoxidase deficient. The other proband with a comparably low mean peroxidase index (proband 2 ) was only partially myeloperoxidase deficient, which was demonstrated by the graphic presentation on Bayer/Technicon H3 (fig. 1), positive peroxidase values in the enzyme immunoassay (tab. 1) and production of $\mathrm{HOCl}$ (tab. 1).

\section{Phagocytosis, chemiluminescence and the respiratory burst}

The chemiluminescence measurement of activated granulocytes with luminol and lucigenin gives an overall picture of the oxidative metabolism without a strong correlation to a distinct kind of reactive oxygen compound. However, it is known that luminol chemiluminescence rather reflects myeloperoxidase $/ \mathrm{H}_{2} \mathrm{O}_{2}$ /chlorite-dependent processes $(19,20)$ whereas lucigenin chemiluminescence is more predictive for $\mathrm{O}_{2}^{\dot{-}}$-dependent reactions $(21,22)$. The luminol dependent chemiluminescence signal was indeed drastically reduced in the proband with complete myeloperoxidase deficiency. It was also clearly diminished in proband 2 with a similar low mean peroxidase index, but still retained some myeloperoxidase activity. The other three probands with partial myeloperoxidase deficiency did not differ from controls to a greater extent, even if they clearly produced reduced amounts of $\mathrm{HOCl}$. This indicates the complex interplay between $\mathrm{H}_{2} \mathrm{O}_{2} / \mathrm{HOCl}$ in the generation of the luminol dependent chemiluminescence signal $(16,23)$.

In contrast, myeloperoxidase deficient granulocytes showed a much higher lucigenin dependent chemiluminescence than normal controls. This characteristically high increase of lucigenin dependent chemiluminescence compared to the striking decrease of luminol dependent chemiluminescence in granulocytes with myeloperoxidase deficiency versus normal controls may be used as a simple test to detect myeloperoxidase deficient probands, if an automatic blood counter of the Bayer/ Technicon H3-type (measuring myeloperoxidase activity) is not available. The enhanced superoxide anion production (lucigenin chemiluminescence) in myeloperoxidase deficient cells was described in the literature (15, $16,23,24)$, and may be caused by two main reasons: Hasui et al. (25) and Stenduhl et al. (26) reported an enhanced phagocytosis of myeloperoxidase deficient granulocytes. This report stands in contrast to earlier observations of Cramer et al. (27) and Larrocha et al. (28), who demonstrated a normal phagocytic behaviour of the myeloperoxidase deficient granulocytes. We could confirm the results that myeloperoxidase deficient granulo- cytes are able to phagocytose more particles than normal ones (tab. 1). The elevated lucigenin dependent chemiluminescence observed in all the five myeloperoxidase deficient patients investigated is probably associated with this enhanced phagocytosis.

The enhanced phagocytosis could be due to increased receptor expression (complement 3b-, Fc-receptor) on the surface of myeloperoxidase deficient granulocytes, which may contribute to the complex pattern of luminol and lucigenin chemiluminescence $(29,30)$. In myeloperoxidase deficient cells, additional numbers of these receptors may be more easily translocated from an intracellular pool to the cell membrane during stimulation (31). This is in agreement with Stendahl et al. (26), who showed that the addition of extracellular myeloperoxidase in zymosan-activated adherent myeloperoxidase deficient granulocytes decreased the complement $3 b-$ and Fc-mediated phagocytosis.

Furthermore, the longer duration of the lucigenin chemiluminescence signal in myeloperoxidase deficient granulocytes compared to normal cells (i.e. the prolongated fall of chemiluminescence signals after the peak-maximum, indicated as $t_{1 / 2 \text { fall }}$, tab. 2) may also reflect the fact that inhibition of NADPH-oxidase is retarded. This is probably due to the absence or low levels of $\mathrm{HOCl}$, which contributes to the termination of the respiratory burst in myeloperoxidase-positive granulocytes (4).

The enhanced production of reactive oxygen compounds as a result of these effects (enhanced phagocytosis due to increased complement $3 \mathrm{~b}$, Fc-receptor expression and reduced inhibition of NADPH-oxidase because of the lack of $\mathrm{HOCl}$ production) may, at least partly, compensate for myeloperoxidase deficiency.

\section{Role of $\mathrm{H}_{2} \mathrm{O}_{2}$ in myeloperoxidase deficient cells}

Lack of myeloperoxidase implies the missing formation of $\mathrm{HOCl}$ from $\mathrm{H}_{2} \mathrm{O}_{2}$, which is a process with a high turnover rate. It was, therefore, expected that the steadystate concentration of $\mathrm{H}_{2} \mathrm{O}_{2}$ would be significantly higher in myeloperoxidase deficient cells after activation. However, although a slightly elevated $\mathrm{H}_{2} \mathrm{O}_{2}$ concentration could be detected, the absolute concentration was rather low in both myeloperoxidase positive and negative cells. Nauseef et al. (15) and Locksley et al. (16) detected normal endogenous amounts of catalase and glutathione-peroxidase in myeloperoxidase deficient granulocytes and monocytes, indicating a normal $\mathrm{H}_{2} \mathrm{O}_{2}$ scavenging system in deficient cells. This finding obviously points to the effective transformation of $\mathrm{H}_{2} \mathrm{O}_{2}$ into other reactive oxygen substrates in the absence of myeloperoxidase, which may be compensatorily cytotoxic. The exact species are presently not known (32). Possible 
candidates in granulocytes and monocytes could be $\mathrm{OH}$ radicals, NO/ONOO formation, as well as substances such as neopterin, which was previously described as an enhancer of cytotoxic effects of $\mathrm{H}_{2} \mathrm{O}_{2}$ against $E$. coli

\section{References}

1. Johnson KJ, Varani J, Smolen, JE. Neutrophil activation and function in health and disease. In: Coffrey RG, editor. Granulocyte responses to cytokines. New York, Basel, Hong Kong: Marcel Dekker, Inc. 1994:1-46.

2. Sakamaki K, Tomonaga M, Tsukui K, Nagata S. Molecular cloning and characterization of chromosomal gene for human cosinophil peroxidase. J Biol Chem 1989; 264:16828-36.

3. Nauseef WM. Myeloperoxidase deficiency. Hematol/Oncol Clin North Am 1988; 2:135-58.

4. Hurst JK, Barrette WC Jr. Leukocytic oxygen activation and microbicidal oxidative toxins. Crit Rev Biochem Mol Biol 1989; 24:271-328.

5. Kutter D, Hendriks JP, Missenard C, Musilovà L, Winter F. Der Myeloperoxidase-Index der Hämatologie-Automaten von Bayer Diagnostics. GIT Labor-Medizin 1994; 2:68-72.

6. Lippi U, Bellavite P, Schinella M, Nicoli M, Lippi G. High light scatter by neutrophils in the Bayer-Technicon $\mathrm{H}^{*} 2$ analyzer: a screening test of morphologically defective responsiveness to in vitro chemotactic stimulation. Eur J Clin Chem Clin Biochem 1994; 32:11-7.

7. Ansley H, Ornstein L. Enzyme histochemistry and differential white cell counts in the Technicon Hemalog D. 1970 Technicon Int Congr Vol 1. Tarrytown, NY, Mediad Inc, 1971; 5-13.

8. Ornstein $\mathrm{L}$, Ansley $\mathrm{H}$, Saunders A. Improving manual differential white cell counts with cytochemisty. Blood Cells $1976 ; 2: 557$.

9. Metcalf JA, Gallin JI, Nauseef WM, Root RK. Laboratory manual of neutrophil function. New York: Raven Press, 1986.

10. Hansel TT, De Vries IJM, Iff T, Rihs S, Wandzilak M, Betz S, Blaser K, Walker C. An improved immunomagnetic procedure for the isolation of highly purified human blood eosinophils. $\mathrm{J}$ Immunol Methods 1991; 145:105-10.

11. Mayo LA, Curnutte JT. Kinetic microplate assay for superoxide production by neutrophils and other phagocytic cells. Methods Enzymol 1990; 186:567-75.

12. Weiss SJ, Klein R, Slivka A, Wie M. Chlorination of taurine by human neutrophils. Evidence for hypochlorous acid generation. J Clin Invest 1982; 70:598-607.

13. Kettle AJ, Winterbourn CC. Assays for the chlorination activity of myeloperoxidase. Methods Enzymol 1994; 233:502-12.

14. Ohno Y, Gallin JI. Diffusion of extracellular hydrogen peroxide into intracellular compartments of human neutrophils. J Biol Chem 1985; 260:8438-46.

15. Nauseef WM, Metcalf JA, Root RK. Role of myeloperoxidase in the respiratory burst of human neutrophils. Blood 1983; 61:483-93.

16. Locksley RM, Wilson CB, Klebanoff SJ. Increased respiratory burst in myeloperoxidase-deficient monocytes. Blood 1983; 62:902-9.

17. Kutter D, Al Haidari K, Thoma J. Einfache Methoden der Diagnostik und Bedeutung der verschiedenen Formen des Myeloperoxidasemangels. Klin Lab 1994; 4:337-41.

18. Selsted ME, Miller CW, Novotny MJ, Morris WL, Koeffler HP. Molecular analysis of myeloperoxidase deficiency shows heterogenous patterns of the complete deficiency state manifested at the genomic, mRNA, and protein levels. Blood 1993; 82:1317-22.

19. Nishida A, Kimura H, Sugioka K, Nakano M. The ability of granulocytes to generate superoxide anions and hypochlorite during phagocytosis: comparison of neonatal granulocytes with adult granulocytes. Biol Neonate 1990; 58:145-51.
(33). The experiments for the identification of these alternative $\mathrm{H}_{2} \mathrm{O}_{2}$-pathways in myeloperoxidase deficient cells are in progress.

20. Müller-Peddinghaus $R$. In vitro determination of phagocyte activity by luminol- and lucigenin-amplified chemiluminescence. Int J Immunopharmac 1984; 6:455-66.

21. Minkenberg I, Ferber E. Lucigenin-dependent chemiluminescence as a new assay for $\mathrm{NAD}(\mathrm{P}) \mathrm{H}_{-}$-oxidase activity in particulate fractions of human polymorphonuclear leukocytes. J Immunol Methods 1984; 71:61-7.

22. Mishra A, Dayal N, Beck-Speier I. Effect of sulphite on the oxidative metabolism of human neutrophils: studies with lucigenin- and luminol-dependent chemiluminescence. J Biolumin Chemilumin 1995; 10:9-19.

23. Kitahara M, Eyre HJ, Simonian Y, Atkin CL, Hasstedt SJ. Hereditary myeloperoxidase deficiency. Blood 1981; 57:888-93.

24. Rosen $\mathrm{H}$, Klebanoff SJ. Chemiluminescence and superoxide production by myeloperoxidase-deficient leukocytes. J Clin Invest $1976 ; 58: 50-60$.

25. Hasui M, Hirabayashi Y, Hattori K, Kobayashi Y. Increased phagocytic activity of polymorphonuclear leukocytes of chronic granulomatous disease as determined with flow cytometric assay. J Lab Clin Med 1991; 117:291-8.

26. Stendahl O, Coble BI, Dahlgren C, Hed J, Molin L. Myeloperoxidase modulates the phagocytic activity of polymorphonuclear neutrophil leukocytes. Studies with cells from a myeloperoxidase-deficient patient. J Clin Invest 1984; 73:366-73.

27. Cramer R, Soranzo MR, Dri P, Rottini GD, Bramezza M, Cirielli $\mathrm{S}$ et al. Incidence of myeloperoxidase deficiency in an area of northern Italy: histochemical, biochemical and functional studies. Br J Haematol 1982; 51:81-7.

28. Larrocha $C$, Fernández de Castro $M$, Fontan G, Viloria A, Fernández-Chacón $\pi$, Jiménez $C$. Hereditary myeloperoxidase deficiency: study of 12 cases. Scand J Haematol 1982; 29:389-97.

29. Dwenger A, Schweitzer G. Bronchoalveolar lavage fluid and plasma proteins, chemiluminescence response and protein contents of polymorphonuclear leukocytes from blood and lavage fluid in traumatized patients. J Clin Chem Clin Biochem 1986; 24:73-88.

30. Lindena J, Burkhardt $H$, Dwenger A. Mechanisms of non-opsonized zymosan-induced and luminol-enhanced chemiluminescence in whole blood and isolated phagocytes. J Clin Chem Clin Biochem 1987; 25:765-78.

31. O'Shea JJ, Brown EJ, Seligman BE, Metcalf JA, Frank MM, Gallin JI. Evidence for distinct intracellular pools of receptors for C3b and C3bi in human neutrophils. J Immunol 1985; 134:2580-7.

32. Rosen GM, Pou S, Ramos CL, Cohen MS, Britigan BE. Free radicals and phagocytic cells. FASEB J 1995; 9:200-9.

33. Weiss G, Fuchs D, Hausen A, Reibnegger G, Werner ER, Werner-Felmayer $G$ et al. Neopterin modulates toxicity mediated by reactive oxygen and chloride species. FEBS Lett 1993; $321: 89-92$.

\section{Received May 5/August 12, 1996}

Corresponding author: PD Dr. Gernot Bruchelt, Abt. Hämatologie und Onkologie, Universitäts-Kinderklinik, Rümelinstr. 19, D-72070 Tübingen, Germany 